\title{
Clarification of the terminology used for description of calcium transport in different cell types
}

\author{
E. ̇̀. Saftenku', J. Sneyd ${ }^{2}$ \\ ${ }^{1}$ O.O. Bogomoletz Institute of Physiology of National Academy of Science of Ukraine, Kyiv; \\ e-mail:esaft@biph.kiev.ua; \\ ${ }^{2}$ The University of Auckland, Auckland, New Zealand
}

Some basic scientific terms in the field of general physiology that studies intracellular calcium transport have a multitude of definitions in the scientific literature. In this article we analyze these definitional ambiguities and try to clarify some basic terms used for the description of calcium transport in cells. The use of ambiguous scientific terminology and conflicting definitions may be a source of misunderstanding among scientists.

Key words: $\mathrm{Ca}^{2+}$ transport; flux; common pool models; all-or-none $\mathrm{Ca}^{2+}$ release; definitional ambiguity.

\section{INTRODUCTION}

$\mathrm{Ca}^{2+}$ transport by the endoplasmic reticulum (ER) plays a crucial role in the regulation of intracellular $\mathrm{Ca}^{2+}$ signals. Some of the terms which are used for the description of $\mathrm{Ca}^{2+}$ transport in different cell types are defined ambiguously in the scientific literature. The increased use of physical terms in biology and their replacement by colloquial terms often results in multiple meanings and inconsistencies in definitions of such basic terms as flux, all-or-none and regenerative $\mathrm{Ca}^{2+}$ release, common pool models, etc. The definitional ambiguities make research within the field of general physiology and biophysics difficult to reconcile. Clarifying the meaning of scientific terms is thus a pressing need.

\section{Ambiguous term "flux" in biological literature}

Flux is a basic concept for the study of transport phenomena in physics and biology. The change in the $\mathrm{Ca}^{2+}$ concentration in the cytosol and ER, which is called sarcoplasmic reticulum (SR) in muscle cells, occurs due to $\mathrm{Ca}^{2+}$ fluxes through the membranes surrounding the cellular compartments, i.e., the cytosol, ER, and (C) E.È. Saftenku, J. Sneyd mitochondria, and $\mathrm{Ca}^{2+}$ buffering. In physics, transport flux is defined as the rate of flow of some quantity per unit area [1] that in the case of mass transfer is expressed in $\mathrm{mol} \mathrm{m} \mathrm{m}^{-2} \mathrm{~s}^{-1}$. The surface integral of the flux represents the quantity, which passes through the surface per unit time. Flux can also be defined, e.g. electric and magnetic flux in electromagnetism, as the surface integral of a vector field [2]. Due to the conflicting definitions, this term sometimes is used ambiguously, especially in the biophysical and physiological literature, where the term "flux" may be defined as the rate of quantity that passes through a fixed boundary and expressed in $\mathrm{mol} \mathrm{s}^{-1}$, e.g., in [3-5], or as the rate of change of calcium concentration and expressed in mol $1^{-1} \mathrm{~s}^{-1}$, e.g., in [6-9]. The latter definition may include $\mathrm{Ca}^{2+}$ binding with buffers, e.g., [10-12], or may refer only to $\mathrm{Ca}^{2+}$ transport between intracellular compartments, e.g., [13]. Sometimes both definitions are used in the same paper [14, 15]. Surprisingly, the strictly physical definition of flux in the case of mass transfer also can be found in the biological literature [16]. In the latter paper a partial derivative of the concentration of a molecular species is equal to the divergence (or the surface integral divided by 
the volume) of the flux. To avoid a significant terminological ambiguity, we suggest using the definition that describes the derivatives of $\mathrm{Ca}^{2+}$ concentrations as "the rate of change in calcium concentration" instead of "fluxes". It seems to be a good practice to designate these derivatives by some other symbol than $J$, which is traditionally used to designate the term "flux" despite of its meaning. For example, in [17] the symbol $R$ was used. As regards the term "flux", it may be acceptable to define it as the surface integral of the rate of transport of some quantity. In this sense, the term "net flux" that is frequently used in the biological literature means the difference between the two unidirectional fluxes, influx and efflux. Net $\mathrm{Ca}^{2+}$ uptake means the difference between uptake and release fluxes, and net $\mathrm{Ca}^{2+}$ release means the difference between release and uptake fluxes [6].

In any case, a great care is needed when the term "flux" is used to define some quantities in equations, and papers should always be careful to give the units of these quantities explicitly. This problem becomes especially pronounced when the intercellular movement of $\mathrm{Ca}^{2+}$ between interconnected cells is modelled.

Clarification of the term " $\mathrm{Ca}^{2+}$-induced calcium release", the modes of $\mathrm{Ca}^{2+}$-induced calcium release and its attributes

$\mathrm{Ca}^{2+}$ release from the ER/SR is executed by two families of calcium-release channels, the ryanodine receptors (RyRs), the $\mathrm{Ca}^{2+}$-gated $\mathrm{Ca}^{2+}$ channels, and the inositol 1,4,5-trisphosphate $\left(\mathrm{IP}_{3}\right)$ receptors. $\mathrm{Ca}^{2+}$-induced calcium release (CICR) usually is defined as $\mathrm{Ca}^{2+}$ release from intracellular stores activated by calcium alone, i.e. via RyRs, and $\mathrm{Ca}^{2+}$ release via $\mathrm{IP}_{3}$ receptors is termed $\mathrm{IP}_{3}$-induced $\mathrm{Ca}^{2+}$ release (e.g., $[18,19]$ ). However, in some papers, CICR was defined as $\mathrm{Ca}^{2+}$ release via both RyRs and $\mathrm{IP}_{3}$ receptors (e.g., [20]). The term CICR is so widely used that the authors usually do not give its definition, and it is not clear without an additional context, which exactly processes they mean. The definition of CICR was discussed in the review of $\mathrm{M}$.
Endo [21]. The author outlines that in the case of the $\mathrm{IP}_{3}$ receptor, $\mathrm{Ca}^{2+}$ can cause $\mathrm{Ca}^{2+}$ release only in the presence of $\mathrm{IP}_{3} \cdot \mathrm{Ca}^{2+}$ release at a constant $\mathrm{IP}_{3}$ concentration can be considered CICR, but if $\mathrm{Ca}^{2+}$ is not, by itself, sufficient to evoke $\mathrm{Ca}^{2+}$ release, such $\mathrm{Ca}^{2+}$ release cannot be considered as CICR. Therefore, although both types of receptors exhibit positive feedback where $\mathrm{Ca}^{2+}$ potentiates its own release, CICR should be considered as an exclusive property of RyRs.

To characterize $\mathrm{Ca}^{2+}$ release from the endoplasmic reticulum (ER) in nerve cells, the term "CICR modes" was introduced $[6,13]$ and three modes of CICR, attenuated net uptake, graded net release and regenerative net release were characterized. These modes were simulated for a fixed $\mathrm{ER} \mathrm{Ca}^{2+}$ concentration. In the first mode, $\mathrm{Ca}^{2+}$ uptake into the ER by sarco(endo)plasmic reticulum $\mathrm{Ca}^{2+}$ ATPases is faster than $\mathrm{Ca}^{2+}$ release from the ER and is attenuated by $\mathrm{Ca}^{2+}$ release. Since "attenuated net $\mathrm{Ca}^{2+}$ uptake" as a model of "release" [6] sounds a little confusing, a more rigorous term that has a clear meaning could be "the modes of net ER $\mathrm{Ca}^{2+}$ transport" instead of "CICR modes". The modes of net ER $\mathrm{Ca}^{2+}$ transport can be characterized by several attributes, such as the direction of net ER $\mathrm{Ca}^{2+}$ flux across the ER membrane, the regenerative or non-regenerative behavior, gradation by $\mathrm{Ca}^{2+}$ influx, and CICR gain.

The direction of the net ER $\mathrm{Ca}^{2+}$ flux determines if the ER acts as a sink or a source [22]. CICR and $\mathrm{IP}_{3}$-induced calcium release are both intrinsically self-reinforcing processes since the release of $\mathrm{Ca}^{2+}$ leads to regenerative RyR and $\mathrm{IP}_{3}$ receptor activation. However, net $\mathrm{CICR}$ and $\mathrm{IP}_{3}$-induced calcium release do not have regenerative character when ER releases $\mathrm{Ca}^{2+}$ at a rate that is slower than $\mathrm{Ca}^{2+}$ clearance by other pathways. In this case, positive feedback is terminated during the stimulation or at the end of the stimulation (the second mode by Albrecht et al. [6]). In contrary, regenerative net $\mathrm{CICR}$ and $\mathrm{IP}_{3}$ calcium release occur when the ER releases $\mathrm{Ca}^{2+}$ at a rate that is faster than 
$\mathrm{Ca}^{2+}$ clearance by other pathways including slow buffers (the third mode by Albrecht et al. [6]). Net $\mathrm{Ca}^{2+}$ release from the ER may lose its regenerative character when the rate of $\mathrm{Ca}^{2+}$ release is equilibrated with the rate of $\mathrm{Ca}^{2+}$ clearance from the cytosol due to counteracting termination mechanisms. The terms "regenerative CICR" and "all-or-none $\mathrm{Ca}^{2+}$ release" are often used in the scientific literature as synonyms [23-25]. Meanwhile, simulations have revealed that the regenerative character of net CICR indeed does not preclude the release of $\mathrm{Ca}^{2+}$ in a graded manner with increasing stimulus strength due to the counteracting termination mechanisms [26].

The term "gradation of CICR" can be defined as proportionality of $\mathrm{Ca}^{2+}$ release flux to the $\mathrm{Ca}^{2+}$ influx through plasma membrane $\mathrm{Ca}^{2+}$ channels, which can be linear ("smooth") or non-linear [27]. All-or-none CICR is characterized by a maximal $\left[\mathrm{Ca}^{2+}\right]_{i}$ response, which is the same at any strength of a stimulus above the threshold [24]. This happens when the sum of all $\mathrm{Ca}^{2+}$ fluxes into the cytosol cannot be compensated by counteracting termination mechanisms, all effluxes and $\mathrm{Ca}^{2+}$ binding with slow buffers. Whether regenerative net $\mathrm{Ca}^{2+}$ flux can be a nonlinearly graded function or behave in an all-or-none manner depends on the gain amplification of the $\mathrm{Ca}^{2+}$ transient triggered by $\mathrm{Ca}^{2+}$ current, and the terms "graded" and "regenerative" refer to the distinct attributes of the mode.

There are similarities between $\mathrm{Ca}^{2+}$ dynamics and membrane potential dynamics in excitable cells because they both are described by the same mathematical formalism of nonlinear dynamics [15, 24]. Action potentials (APs), similar to all-or-none $\mathrm{Ca}^{2+}$ release events, are considered as one instance of a broad class of regenerative events caused by intrinsic positive feedback [28]. Graded regenerative potentials are one of the types of such events [29, 30]. Recently large analog fluctuations in membrane potential were discovered in the dendrites of the neocortex in freely behaving rats [31]. Some authors incorrectly termed regenerative events as APs [32]. The amplitude and waveform of APs are invariant with respect to the amplitude, duration, and waveform of the stimulus that evoked it. Unlike the APs, the amplitude and waveform of graded regenerative potentials are highly sensitive to the characteristics of the stimulus. It should be noted that in contrast to membrane potentials, the overwhelming majority of $\mathrm{Ca}^{2+}$ release events are more or less graded and are not similar to APs.

The term "gain of $\mathrm{Ca}^{2+}$ release" is also confusing. Most authors use this term according to the definition suggested by Michael Stern [27] for cardiomyocytes: gain is the ratio of the amount of $\mathrm{Ca}^{2+}$ released from the ER to that amount of $\mathrm{Ca}^{2+}$ which entered into the cells through plasma membrane $\mathrm{Ca}^{2+}$ channels. This definition is applicable to many excitable cells. CICR gain is considered to be low when it is smaller than unity, in which case it provides a robust and graded amplification of the $\mathrm{Ca}^{2+}$ signal in the absence of a counteracting termination mechanism [27, 33]. Alternatively, the term "low gain mode" was used as a synonym of net $\mathrm{Ca}^{2+}$ uptake $[6,13]$.

\section{Common pool models and the models of local control}

Common pool models were defined by $M$. Stern in 1992 [27] as those models in which the trigger $\mathrm{Ca}^{2+}$ and released $\mathrm{Ca}^{2+}$ pass through a common cytosolic pool, and in which all RyRs are controlled by the whole-cell trigger $\mathrm{Ca}^{2+}$ current rather than by local openings of single $\mathrm{Ca}^{2+}$ channels. These models simulate a spatially homogeneous (global) $\mathrm{Ca}^{2+}$ concentration, which is described by only one variable in the whole cell or in each cell compartment [34]. For example, in cardiac cells this occurs when all nanodomains in the junctional, or dyadic, clefts between the sarcolemma and SR coalesce into a single compartment with volume equal to that of all dyads within the cell. Using linear stability theory, M. Stern [27] demonstrated that common pool models cannot achieve both high 
gain and smoothly graded $\mathrm{Ca}^{2+}$ release, which was observed experimentally in cardiomyocytes. To explain this gradation, M. Stern proposed models of local control of CICR in ventricular myocytes that suggest that voltage-dependent $\mathrm{Ca}^{2+}$ channels on the sarcolemma and RyRs on the SR interact via local high $\mathrm{Ca}^{2+}$ elevations within the dyadic cleft. Graded release arises as the result of statistical recruitment of spatially uncoupled $\mathrm{Ca}^{2+}$ release units (CRUs). CRUs were also defined ambiguously as discrete clusters of RyRs [33], or as the set of release channels together with associated voltagedependent $\mathrm{Ca}^{2+}$ channels [35]. Numerous models of $\mathrm{Ca}^{2+}$ sparks (e.g., $\left.[5,10]\right)$ are models of local control where voltage-dependent and release $\mathrm{Ca}^{2+}$ channels communicate through changes in $\mathrm{Ca}^{2+}$ concentration in a restricted subsarcolemmal space, i.e. the trigger $\mathrm{Ca}^{2+}$ and released $\mathrm{Ca}^{2+}$ pass through a common pool.

The clarity of terms characteristic for ventricular myocytes worsens in publications concerning atrial myocytes. In contrast to ventricular myocytes that have a well-developed system of deep sarcolemma invaginations (t-tubules) where L-type $\mathrm{Ca}^{2+}$ channels are localized in the immediate proximity of RyR clusters, only some populations of atrial myocytes have a developed system of t-tubules. Recently a model for a subpopulation of right mouse atrial myocytes with developed transverse-axial tubule system was published [36]. This model is based on the common-pool model in ventricular myocytes with a common dyadic cleft, but the authors claim that their model includes local control of CICR. To model atrial myocytes that do not have a transverse axial tubule system and whose $\mathrm{Ca}^{2+}$ release relies on $\mathrm{Ca}^{2+}$ diffusion from the submembrane regions, spatial models of atrial myocytes were developed. The first models were one-dimensional models where space was divided into several compartments with homogeneous $\mathrm{Ca}^{2+}$ concentrations. The $\mathrm{Ca}^{2+}$ transients are large in the periphery of the cell and small in the cell center. The voltage-dependent $\mathrm{Ca}^{2+}$ current enters into the peripheral subspace compartment only. Into other compartments $\mathrm{Ca}^{2+}$ enters due to diffusion. In the review of Heijman et al. [37], all spatial models are considered as the opposite of common pool models. The authors propose that, similarly to atrial models, ventricular models can be divided into common-pool and spatial local control models [37]. But the same increase in the number of compartments in the models where the trigger calcium and released calcium pass through common cytosolic pool in each compartment and where only macroscopic SR $\mathrm{Ca}^{2+}$ release is described does not make these models different from any other common pool models. The authors of one of such model [38] write that their model shares the general limitations of common pool models such as an approximate description of macroscopic SR $\mathrm{Ca}^{2+}$ release. The same concerns spatial neuronal models, where the space is divided by shell compartments.

A more difficult case is presented by 3-dimensional models. In a recent model of local control in ventricular myocytes [9] with realistic reconstruction of intracellular structures, the dyads and junctional SR were treated as single voxels in the spatial geometries. But in some models of atrial myocytes, where spatial grids were modeled as two-dimensional domains [39, $40]$, the spatial information necessary to model separate dyadic volumes and so $\mathrm{Ca}^{2+}$ concentration that locally controls $\mathrm{Ca}^{2+}$ release into the dyadic space was not provided [39]. In some other models of atrial myocytes, the dynamics of $\mathrm{Ca}^{2+}$ release units was studied in detail at high spatial resolution [40]. Thus, we can see that the terms "common pool models" and sometimes "local control models" do not have accurate definitions and are sufficiently ambiguous to allow for several conflicting interpretations. More rigorous could be the classification of models as spatially homogeneous models (in the whole cell or within each cell compartment) with macroscopic $\mathrm{SR} / \mathrm{ER} \mathrm{Ca}^{2+}$ release versus microdomain models of $\mathrm{Ca}^{2+}$ dynamics and elementary $\mathrm{Ca}^{2+}$ release units. 


\section{CONCLUSIONS}

In order to avoid miscommunication of information and to compare more efficiently the results from different publications, ambiguous scientific terms should be avoided or at least defined explicitly. Moving toward a common terminology would benefit future research.

The authors of this study confirm that the research and publication of the results were not associated with any conflicts regarding commercial or financial relations, relations with organizations and/or individuals who may have been related to the study, and interrelations of coauthors of the article.

O.Е. Сафтенку1, Дж. Снейд²

\section{ПОЯСНЕННЯ ТЕРМІНОЛОГІЇ, ЩО ВИКОРИСТОВУЮТЬСЯ ДЛЯ ОПИСУ ТРАНСПОРТУ КАЛЬЦІЮ В РІЗНИХ ТИПАХ КЛІТИН}

${ }^{1}$ Інститут фізіології ім. О.О. Богомольияя НАН Украӥни, Kü̈; e-mail: esaft@biph.kiev.ua;

${ }^{2}$ Університет Окленду, Окленд, Нова Зеландія.

Деякі основні наукові терміни у галузі загальної фізіології, що вивчає внутріклітинний транспорт кальцію, мають велику кількість визначень в науковій літературі. В цій статті ми аналізуємо неоднозначності визначень і намагаємося з'ясувати деякі основні терміни, що використовуються для опису транспорту кальцію в клітинах. Використання неоднозначної наукової термінології і суперечних визначень може стати джерелом непорозуміння серед вчених. Ключові слова: транспорт іонів кальцію; потік; моделі загального пулу; вивільнення $\mathrm{Ca}^{2+}$ за принципом «все або нічого»; невизначеність визначень.

\section{Е.Э. Сафтенку, Дж. Снэйд}

\section{ПОЯСНЕНИЕ ТЕРМИНОЛОГИИ, КОТО- РАЯ ИСПОЛЬЗУЮТСЯ ДЛЯ ОПИСАНИЯ ТРАНСПОРТА В РАЗНЫХ ТИПАХ КЛЕТОК}

Некоторые основные научные термины в области общей физиологии, которая изучает внутриклеточный транспорт кальция, имеют множественные определения в научной литературе. В этой статье мы анализируем эти неоднозначные определения и пытаемся прояснить некоторые основные термины, которые используются для описания транспорта кальция в клетках. Использование неоднозначной научной терминологии и конфликтующих определений может служить источником непонимания среди ученых.
Ключевые слова: транспорт ионов кальция; поток; модели общего пула; высвобождение $\mathrm{Ca}^{2+}$ по принципу «все или ничего»; неоднозначность определений.

\section{REFERENCES}

1. Bird RB, Stewart WE, Lightfoot EN. Transport phenomena. 2nd ed. New York: John Wiley and Sons; 2006.

2. Spiegel MR, Lipschutz S, Spellman D. Vector analysis. Schaum's Outline Series. 2nd ed. New York: McGrawHill Education; 2009.

3. Blumenfeld H, Zablow L, Sabatini B. Evaluation of cellular mechanisms for modulation of calcium transients using a mathematical model of fura- $2 \mathrm{Ca}^{2+}$ imaging in Aplysia sensory neurons. Biophys J. 1992;63: 1146-64.

4. Friel DD. $\left[\mathrm{Ca}^{2+}\right]_{\mathrm{i}}$ oscillations in sympathetic neurons: an experimental test of a theoretical model. Biophys J. 1995;68:1752-66.

5. Hinch R, Greenstein JL, Tanskanen AJ, Xu L, Winslow RL. A simplified local control model of calcium-induced calcium release in cardiac ventricular myocytes. Biophys J. 2004;87:3723-36.

6. Albrecht MA, Colegrove SL, Hongpaisan J, Pivovarova $\mathrm{NB}$, Andrews SB, Friel DD. Multiple modes of calciuminduced calcium release in sympathetic neurons I: attenuation of endoplasmic reticulum $\mathrm{Ca}^{2+}$ accumulation at low $\left[\mathrm{Ca}^{2+}\right]_{\mathrm{i}}$ during weak depolarization. J Gen Physiol. 2001;118:83-100.

7. Williams GS, Chikando AC, Tuan HT, Sobie EA, Lederer WJ, Jafri MS. Dynamics of calcium sparks and calcium leak in the heart. Biophys J. 2011;101:1287-96.

8. Gin E, Kirk V, Sneyd J. A bifurcation analysis of calcium buffering. J Theor Biol. 2006;242:1-15.

9. Colman MA, Pinali C, Trafford AW, Zhang H, Kitmitto A. A computational model of spatio-temporal cardiac intracellular calcium handling with realistic structure and spatial flux distribution from sarcoplasmic reticulum and t-tubule reconstructions. PLOS Comput Biol. 2017;13:e1005714.

10. Sobie EA, Dilly KW, dos Santos Cruz J, Lederer WJ, Jafri MS. Termination of cardiac $\mathrm{Ca}^{2+}$ sparks: an investigative mathematical model of calcium-induced calcium release. Biophys J. 2002;83:59-78.

11. Shiferaw Y, Watanabe M, Garfinkel A, Weiss JN, Karma A. Model of intracellular calcium cycling in ventricular myocytes. Biophys J. 2003;85:3666-86.

12. Cannell MB, Kong CH, Imtiaz MS, Laver DR. Control of sarcoplasmic reticulum $\mathrm{Ca}^{2+}$ release by stochastic RyR gating within a 3D model of the cardiac dyad and importance of induction decay for CICR termination. Biophys J. 2013;104:2149-59.

13. Albrecht MA, Colegrove SL, Friel DD. Differential regulation of $\mathrm{ER} \mathrm{Ca}^{2+}$ uptake and release rates accounts for multiple modes of $\mathrm{Ca}^{2+}$-induced $\mathrm{Ca}^{2+}$ release. J Gen Physiol. 2002;119:211-33.

14. Patterson M, Sneyd J, Friel DD. Depolarizationinduced calcium responses in sympathetic neurons: 
relative contributions from $\mathrm{Ca}^{2+}$ entry, extrusion, ER/ mitochondrial $\mathrm{Ca}^{2+}$ uptake and release, and $\mathrm{Ca}^{2+}$ buffering. J Gen Physiol. 2007;129:29-56.

15. Friel DD, Chiel HJ. Calcium dynamics: analyzing the $\mathrm{Ca}^{2+}$ regulatory network in intact cells. Trends Neurosci. 2008;31:8-19.

16. Cowan AE, Moraru II, Schaff JC, Slepchenko BM, Loew LM. Spatial modeling of cell signaling networks. Methods Cell Biol. 2012;110:195-221.

17. Hernjak N, Slepchenko BM, Fernald K, Fink CC, Fortin D, Moraru II, Watras J, Loew LM. Modeling and analysis of calcium signalling events leading to long-term depression in cerebellar Purkinje cells. Biophys. J. 2005;86:3790-806.

18. Verkhratsky A. Physiology and pathophysiology of the calcium store in the endoplasmic reticulum of neurons. Physiol. Rev. 2005;85:201-79.

19. Berridge MJ. The inositol trisphosphate/calcium signalling pathway in health and disease. Physiol Rev. 2016;96:126196.

20. Berridge MJ. The endoplasmic reticulum: a multifunctional signalling organelle. Cell Calcium. 2002;32:235-49.

21. Endo M. Calcium-induced calcium release in skeletal muscle. Physiol Rev. 2009;89:1153-76.

22. Friel DD, Tsien RW. A caffeine- and ryanodine-sensitive $\mathrm{Ca}^{2+}$ store in bullfrog sympathetic neurones modulates effects of $\mathrm{Ca}^{2+}$ entry on $\left[\mathrm{Ca}^{2+}\right]_{\mathrm{i} .}$.J Physiol. 1992;450:217-46.

23. Callewaert G, Sipido KR, Carmeliet E, Pott L, Lipp P. Intracellular citrate induces regenerative calcium release from sarcoplasmic reticulum in guinea-pig atrial myocytes. Pflügers Arch. 1995;429:797-804.

24. Usachev YM, Thayer SA. All-or-none $\mathrm{Ca}^{2+}$ release from intracellular stores triggered by $\mathrm{Ca}^{2+}$ influx through voltage-gated $\mathrm{Ca}^{2+}$ channels in rat sensory neurons. $\mathrm{J}$ Neurosci. 1997;17:7404-14.

25. Verkhratsky A. Endoplasmic reticulum calcium homeostasis and neuronal pathophysiology of stroke. In: Annunzio $\mathrm{L}$, editor. New strategies in stroke intervention: Ionic transporters, pumps and new channels. New York: Human Press; 2009. p. 47-64.

26. Saftenku E. Modeling approaches to describe the diversity of the modes of operation of endoplasmic reticulum $\mathrm{Ca}^{2+}$ transport systems in neurons. VII Congress of the Ukrainian Society for Neuroscience; 2017, June 7-11; Kyiv. Abstract book. p. 50-1.

27. Stern MD. Theory of excitation-contraction coupling in cardiac muscle. Biophys J. 1992;63:497-517.
28. Lockery SR, Goodman MB, Faumont S. First report of action potentials in a C. elegans neuron is premature. Nat Neurosci. 2009;12:365-6.

29. Davis RE, Stretton AO. Signaling properties of Ascaris motoneurones: graded active response, graded synaptic transmission, and tonic transmitter release. J Neurosci. 1989;9:415-25.

30. Goodman MB, Hall DH, Avery L, Lockery SR. Active currents regulate sensitivity and dynamic range in $\mathrm{C}$. elegans neurons, Neuron 1998;20:763-72.

31. Moore JJ, Ravassard PM, Ho D, Acharya L, Kees AL, Vuong C, Mehta MR. Dynamics of cortical dendritic membrane potential and spikes in freely behaving rats. Science 2017;355 (6331):eaaj1497.

32. Mellem JE, Brockie PJ, Madsen DM, Maricq AV. Action potentials contribute to neuronal signaling in C. elegans. Nat Neurosci. 2008; 11:865-7.

33. Ouyang K, Wu C, Cheng H. $\mathrm{Ca}^{2+}$-induced $\mathrm{Ca}^{2+}$ release in sensory neurons: low gain amplification confers intrinsic stability. J. Biol. Chem. 2005;280:15898-902.

34. Maltsev VA, Yaniv Y, Maltsev AV, Stern MD, Lakatta EG. Modern perspectives on numerical modeling of cardiac pacemaker cells. J Pharmacol Sci. 2014;125:6-38.

35. Franzini-Armstrong C, Protasi F, Ramesh V. Shape, size, and distribution of $\mathrm{Ca}^{2+}$ release units and couplons in skeletal and cardiac muscles. Biophys J. 1999;77:1528-39.

36. Asfaw TN, Tyan L, Glukhov AV, Bondarenko VE. A compartmentalized mathematical model of mouse atrial myocytes. Am J Physiol Heart Circ Physiol. 2020;318:H484-H507.

37. Heijman J, Erfanian Abdoust P, Voigt N, Nattel S, Dobrev D. Computational models of atrial cellular electrophysiology and calcium handling, and their role in atrial fibrillation. J Physiol. 2016:594:537-53.

38. Koiwumäki JT, Korhonen T, Tavi P. Impact of sarcoplasmic reticulum calcium release on calcium dynamics and action potential morphology in human atrial myocytes: a computational study. PLoS Comput Biol. 2011:7:e1001067.

39. Voigt N, Heijman J, Wang Q, Chiang DY, Li N, Karck M, Wehrens XHT, Nattel S, Dobrev D. Cellular and molecular mechanisms of atrial arrhythmogenesis in patients with paroxysmal atrial fibrillation. Circulation. 2013;129:145-56.

40. Marchena M, Echebarria B. Computational model of calcium signaling in cardiac atrial cells at the submicron scale. Front Physiol. 2018;9:1760.

Received 26.05.2020 